\title{
Beyond the policy-implementation gap How the City of Johannesburg manufactured the ungovernability of street trading
}

\author{
Unedited version of a paper published as:
}

Claire Bénit-Gbaffou (2018) Beyond the Policy-Implementation Gap: How the City of Johannesburg Manufactured the Ungovernability of Street Trading, The Journal of Development Studies, 54:12, 2149-2167, DOI: 10.1080/00220388.2018.1460468

\begin{abstract}
After a decade of increasingly progressive street trading policy in the City of Johannesburg, emphasising the permanence of informal economies in a city marked by mass poverty, extreme inequality and chronic unemployment, the City of Johannesburg embarked on Operation Clean Sweep. In October 2013, the municipality chased 6000 to 8000 street traders from inner city streets, licensed and unlicensed, in breach of the policy and regulations it had itself promulgated. Negotiations between street trader organizations and the City failed, trader organizations took the City to Court, and won. The City had acted illegally, "in flagrant disregard of the traders' rights" (Constitutional Court, 2014: 6). The traders went back to trade, protected by the Court order, and the City started in 2015 a process of trading site demarcation and policy reform: an effort to address the sector issues, but also potentially to "do legally what Operation Clean Sweep could not achieve illegally"1: making the inner city pavements "trader-free", or at least strictly limiting the number of legal trading spaces.
\end{abstract}

This paper aims at placing the Operation in the broader context of the City of Johannesburg's government of street trading. It argues that, far from being an exception contrasting with the street trading policies and institutions developed by the municipality over two decades, the Operation is its logical consequence. Several officials have justified the Operation as a movement of exasperation in the face of their own incapacity to govern street trading in Johannesburg inner city, that they often describe as an "intractable" urban issue: informal trading is just too messy and chaotic to be governed. This "ungovernability" hypothesis has been embraced by other work on Johannesburg inner city, arguing that its urban dynamics are too complex, fluid and contradictory to leave much room for manoeuvre to City officials (Simone, 2004), and that, even if well intentioned, they are only "muddling through" (Lipietz, 2008) rather than governing the city.

Yet, the "ungovernability" hypothesis is far from satisfactory. Through the experience of engaging with City officials, accompanying street trader organisations in their attempt to amend or redress municipal decisions, reviewing and advising on policy documents ${ }^{2}$, the idea of "ungovernability" is deeply limiting. It is limiting politically, as it means a resignation to the status quo, giving up the possibility of imagining policy and urban alternatives. It is limiting academically, not accounting for the strong political and administrative choices that are made repeatedly, regularly contested, and contributing to what everybody recognises as a chronic failure in street trading management.

This frustration is echoed by an inspiring text by Ananya Roy (2009), wondering "why India cannot plan its cities". She demonstrates that the state, an array of public authorities, resorts to informal practices when governing cities, as an "idiom of urbanisation": purposefully creating a situation of spatial, administrative and political uncertainty that serves some of its purposes, including, she argues, capital accumulation through speculation on peripheral land. However, she shows, this 
informality in state practices can also be used against its interventions by a variety of social groups, and contribute to render cities impossible to plan. Roy inspired an interrogation on the extent to which informality and the long lasting "intractability" of the government of street trading in Johannesburg was, if not intentional, at least serving coalitions of interests within the state. Further, when examining the instruments used by City officials to govern street trading, one is led to interrogate whether the choices made by the municipality have not in fact directly (if partly) manufactured the ungovernability of the "sector" 3 . This interrogation is at the core of this paper.

The paper starts by questioning the "urban ungovernability" thesis, which argues, in diverse and scattered ways, that large cities (especially in the global South) are becoming impossible to govern. Based on the conceptualization of ungovernability developed in the first section, the second part of the paper reflects on how street trading in post-apartheid Johannesburg has been governed since the late 1990s, and argues that the municipality has itself partly manufactured the ungovernability of street trading, through the instruments and non-instruments it has designed and used to govern the sector.

\section{Have large cities become "ungovernable"?}

The question of whether municipalities of large metropolitan areas are incapable of planning their cities, or if they purposefully use the state's internal complexities, contradictions and divisions and play on the multiple and divided external pressures, to pursue specific agendas (Roy, 2009), needs to be replaced in a broader, multidisciplinary academic field. Firstly, the concept of ungovernability is a fuzzy one, and has been used in a diversity of contexts with different meanings to characterise cities since the 1960s. Secondly, for a number of reasons, dominant research in social sciences on urban governance (political, policy, public administration, urban studies, anthropology and urban politics) has shifted its gaze and conceptual apparatus away from analysing the state's "capacity to govern". It has instead focused on networks and coalition-building processes, on unintended or arbitrary effects of state planning interventions, with limited emphasis on what these coalitions, networks and interventions actually produce in contemporary cities. Based on this analysis, the section proposes a conceptualization of ungovernability that assists in reframing an interrogation on the state's capacity to steer, in specific sectors or areas of society, and argues for an interrogation of policy objectives through a genealogy of policy instruments.

\subsection{The fuzzy yet appealing concept of "ungovernability"}

The question of the governability of large urban areas is resurfacing in contemporary urban studies scholarship (Roy, 2009; Borraz and Le Galès, 2010; Aguilera, 2012; Heller, 2016). Cities are said to be, or to have become, increasingly difficult to govern: meaning that public authorities are no longer (have they ever been?) able to actively shape urban areas and societies, to influence their development and their form, let alone to steer them in specific economic, spatial or social directions.

In cities of the North, the diminishing governability of cities is blamed on dynamics of economic globalization, and the limited autonomy of national and local government confronted to increasingly powerful transnational market forces. Political crises of representation are adding to the ungovernability thesis - where it becomes far more difficult than in the previous century to sustainably mobilise strong and consistent constituencies, in an age of social individualization and discredit cast over classic political parties. An additional and key dimension of metropolitan ungovernability, I argue, can be attributed to the complexification of state machinery, under a double influence. This complexification is first the result of neoliberalisation processes, leading to the proliferation of parastatal or semi-private agencies, outsourcing practices, partnerships and delegated functions, all needing to be monitored and generating their own, new bureaucracies (Hibou, 2012). But the complexification of the state is also due, concurrently, to dynamics of decentralization, building a multi-layered state with daunting issues of coordination and overlapping functions. This institutional complexity is particularly prevalent at the urban scale, where various 
levels of the state intervene, in coordinated or uncoordinated ways, to craft and implement urban policies.

In democratising cities of the South, these trends exist but the question of governability is framed in slightly different terms. Various studies implicitly pointing to urban ungovernability explain the difficulty to plan and govern cities by the rapid pace and large scale of urbanization, unheard of in urban history (Le Galès and Lorrain, 2003; Heller, 2016); the sheer extent of urban poverty that is incommensurate with public resources (Davis, 2007) and is leading to the persistence of vast groups of "informal people" (Chatterjee, 2004), the proliferation of "grey spaces" waiting for legalization or destruction in a legal limbo (Yiftachel, 2009), managed rather than governed by the state (Anjaria, 2010). Authors emphasise the fluidity and instability of individual and groups affiliations and belonging (Simone, 2004; Lindell, 2008), rendering unlikely the emergence of stable urban regimes (Lipietz, 2008; Weinstein, 2008). Other scholars stress, at national level mostly, the recent and heterogeneous character of developing states (Bierschenck and Olivier de Sardan, 2007; Gupta, 2012), not armed with consistent and capacitated bureaucratic apparatus, and rivalled by multiple layers of legitimacy, rights and authority (Lund, 2006). To this, authors increasingly add the recurrence of violence and risk of political instability, and their effect on states' ability to govern democratically (Holston, 2009; Von Holdt, 2013).

The term "ungovernability" is actually seldom used by these authors, from the North as from the South. If it is used, it is often only mentioned in passing, as a layman's term rather than as a concept (Gordon \& Travers, 2010; Chance, 2015; Recio, 2015). Few authors directly question the municipal ability to govern - with the notable and recent exception of scholars working on Indian cities, which combine high degrees of urban complexity, explicit developmental state ambitions, and are studied by a scholarship interested in reconceptualising the state. Ananya Roy explicitly tackles the issue in her 2009 paper, "Why India cannot plan its cities" - and explains that this incapacity has been created by the state's own practices, intentionally using informality (opacity, persistent nondecisions, chronic contradictions, contravention of its own rules) as an "idiom of urbanization", an instrument to create uncertainty and flexibility, "un-map" parts of its territories for purpose of land speculation. The state is in turn victim of its own device, as multiple stakeholders use this regulatory fuzziness to sue and block its interventions, at the implementation rather than the policy level, in a piecemeal way rather than as strategic opposition, but nevertheless with huge impacts on the state's ability to govern. Benjamin (2004) stresses the multiple overlays of proliferating public categories for identifying and regularising informal settlements in India, and analyses how this complexity creates room for manoeuvre for local officials (a "porous bureaucracy"), in contradiction with higher level and ill-adapted strategic master plans. Starting from a similar observation, Heller (2016) is more critical, reading these administrative complexities and institutional contradictions in Indian cities as creating urban spaces that are "not governed".

Why is the term of city "ungovernability" so scarce in scholarly interrogations around issues that pertain to the state's ability to govern cities? Governability and ungovernability, as concepts, have a contested political history, at least in the field of political studies, as reminded by Kooiman, who talks about its "dubious scholarly standing" when it was first coined by Crozier, Huntington and Watanuki (1975, quoted in Kooiman 2008). The three authors argued that states had decreasing ability to govern due to the conjunction of increasing social expectations by various sectors of society, and decreasing state authority, contested by social movements in particular. Their report was aimed at criticising the American Great Society social programmes, and forms of "new activism" that they saw as placing excessive and illegitimate pressure on the state. The argument of the ungovernability of (North American) society was therefore first framed within a reactionary political ideology, to call for a state that would be more top-down and centralised, and less intervening in social matters. Kooiman (2008) refers however to a second lineage, and less politically instrumental use of the concept, revolving around the German debates on "governance and governability". These debates 
question states' ability to steer society through an analysis of the capacity of groups to resist states' intervention and regulation (Mayntz, 2006). They displace the focus from the state's capacity to govern, to societies' resistance to being governed, and emphasise the shift to "governance" as a way to mitigate this resistance, by regularly interacting with social groups in policy design and implementation processes ${ }^{4}$. Kooiman also briefly mentions a third wave of theorisation, stemming mostly from Brazilian political studies, where the concept of governability interrogates states' ability not only to steer society, but also to maintain stability and legitimacy, and avoid eruptions of violence (Pereira and Orellana, 2009; Bruera, 2013). This conceptual shift, coming from democratising societies from the South, is interesting: the concern for governability centred on states' capacities is going beyond efficiency and policy goals achievement, to embrace the state's ability to accommodate political conflict without violence. Similar debates can also be found in Indian literature (Kohli, 1991), and as starting to emerge in South Africa, although not framed in terms of governability (Von Holdt, 2013).

In parallel to these debates mostly grounded in political studies and focusing on the national state level, there is a second trajectory of the notion of ungovernability, somehow disconnected from the first, in the field of urban politics. The seminal work is Yates' book, Ungovernable City (1977), holding together different dimensions of what makes governing cities a daunting task. On the one hand, cities are seen as incredibly complex systems, combining high level of diversity (of people, of interests, of issues) and density (as potential for interaction). This makes "problems hard to disentangle and greatly increase[s] the likelihood that policy has unintended consequences" (Gordon and Travers, 2010: 49). On the other hand, Yates argues, mayors are caught between several conflicting obligations: responding to the direct complaint of constituencies, overcoming the inertia or resistance of powerful bureaucracies, and managing external relations in the hope of garnering resources to act. This theorization of ungovernability mixes a thorough analysis of urban issues' complexity (as "systems to be governed", to use Kooiman's conceptualisation: 2008), and a deep understanding of the internal politics of an institution such as local government (as "systems to govern": Kooiman, 2008), that render steering particularly difficult.

Yates' concept of urban "ungovernability" has been used by many scholars in urban politics, mostly to study large metropoles from the UK and the US (Ferman, 1983, 1985; Gordon and Travers, 2010). However few elaborate theoretically on Yates' concept, rather used to emphasise the challenges and opportunities of leadership, and to interrogate how mayors navigate internal and external politics in a given context, rather than investigating how they manage or fail to shape their cities (Ferman, 1983). Closer to Yates' theoretical ambition perhaps is the work of Clarence Stone, who does not use the term "governability" but identifies the "capacity to govern" as one of the key pillars of his theory of urban regimes (Stone, 1993). He suggests that power in urban politics should be primarily approached as "the power to" (to act, to govern a city) rather than only as "power over" (to dominate, to influence others). Whilst he has argued that the capacity to govern a city is based on the ability to build and maintain coalitions between state and non-state agents (in particular business groups) in order to mobilise the resources needed for urban change, he never forgets to also reflect on the nature of the urban issues at stake, how regimes tackle them, and are able or not "to make a difference" vis-a-vis ongoing market trends that would happen anyway (Stone, 2005).

In this respect, Stone differs from most analysts of urban "governance", a field of study emerging in the 1990s and that stresses the (normative and analytical) shift away from "government", and the importance of non-state agents in governing societies, in interaction with the state. Many studies in terms of governance (and urban governance in particular) have indeed focused on the complex architecture of coalitions, networks and institutions built between a multiplicity of agents - shying away, arguably, from the question of policy intention and steering, and where governance loses its core meaning of "giving a direction" (Peters, 1997). This shift might reflect the actuality of state officials' preoccupations, where 
"the task of consolidating fragmented planning and governance arrangements into new city-region institutions has inexcusably distracted policy elites [from...] searching out positive solutions to urban and regional problems - surely the fundamental goal of any form of urban and regional governance" (Harrison \& Hoyler, 2014: 2255).

\subsection{Lost in translation? Conceptualising states' policy objectives in urban governance}

This shift away from goal-setting towards alliance-building could be attributed to the sheer complexity of the networks and arrangements at play, conceptualised in a multiplicity of terms (depending on contexts, discipline and political affinity): regimes, partnerships, coalitions, ephemeral assemblages, etc. This complexity possibly captures both politicians' energies and the researchers' gaze, at the expense of assessments or analyses of policy outcomes: the power to do... what? The shift could also be explained by the theoretical impossibility of conceptualising a clear policy objective in a governance era, or in the analytical framework of "governance". If processes of decision-making and policy-design are fluid and multi-layered, influenced by a diversity of state and non-state actors with differing interests, visions and goals, through iterative, multiple, and entangled processes, policies become political compromises or inconsistent patchworks of various agents' interests, rather than a declaration of public intent, let alone a choice between conflicting values and options.

This complexification of governance (both in practice and in research lens) and the difficulty of conceptualising state's capacity to steer in that context, is reflected in the debates around policy design (Linder \& Peters, 1987), policy implementation (Winter, 2006), developmental studies (Mosse, 2004), and ethnographies of the state (Das \& Poole, 2004; Bierschenk and Olivier de Sardan, 2007; Gupta, 2012). Many analysts of state make it virtually impossible to believe that any policy can be successfully implemented and achieve intended effects. Gupta (2012) for instance, in his bottom-up study of bureaucratic practices in the Indian developmental state, concludes that in spite of good intentions (the welfare and development of the poor), Indian state's policies are intrinsically arbitrary in their outcomes, caught in the web of complex administration, contexts and official agencies.

This incapacity to interrogate and conceptualise policy goals is further aggravated by an increasingly dominant view of governance that sees it as a form of "cooperation" and "compromise" between state and non-state agents (Mayntz, 2006), often excluding or sanitising notions of conflicts or clash of interests - except perhaps for specific problems characterised as "intractable" (Scholten, 2013). But even then, the governability issue is framed as stemming from the specificity of the issue at stake, rather than from the constellation of stakeholders intervening in its governance or the possibility of conflicting interests. In this view of governance as "cooperation" (or the impossibility thereof), mayors are often viewed as mere "facilitators" (Borraz and John, 2004; Greasley and Stoker, 2008), rather than leaders with a constructed vision for their City (even if flexible and contextrelated). In brief, it seems that either urban leadership is no longer able to steer, or urban governance studies have moved away from interrogating "governing", "steering", "making choices" and "defining policy objectives" in their analyses of governing and leadership.

Granted, the notion of policy objective no longer can be conceptualised as a "grand plan", clear and consistent from the onset, and carried out systematically and efficiently by one or a few independent and powerful agents. But this legitimate critique of power seems to have disabled researchers from explaining first a degree of political choice and agency (even if marked by incremental consolidation, trial and error, opportunistic consolidation and backtrack processes); and secondly the existence of strong policy continuities, convergence of sets of policy decisions, budgetary choices and instruments elaboration that produce consistent and mutually reinforcing effects on social and urban realities. Has the "invisible hand" of networked governance replaced the one of the market to explain regularities in areas of policy intervention - that have become too opaque and complex to even attempt to analytically grasp? 
We follow Linder and Peters (1987), and Le Galès and Lorrain (2003), in refusing this (pessimistic) position, that can be critiqued as either intellectual laziness, or ideological encapsulation limiting our ability to question and research social realities. Our blindness to unpack and conceptualise state steering can indeed be seen as the result of the paradoxical convergence of neoliberal agenda (states are inefficient and corrupt, they should not interfere, they no longer matter) and postmodern critiques against the state (states do not exist, or are evil forces, or are too complex and inconsistent to drive social change). Following Stone, we do not want to give up studying policy goal-setting and political steering as key to the act of governing:

"Governing is active policy making, it is about neither what is settled, nor about broad changes taking shape outside the intentions of policy makers. Governing consists of deliberate efforts to bring about or actively prevent policy changes. It is selective in what is addressed, both in substantive terms (addressing 'this' while not addressing 'that') and in scope (falling in each instance somewhere in a range from tinkering with narrow particulars to efforts to remake large slices of city life)." (Stone, 2013: 4)

What is illuminating in Stone's view is that the ability for the state (and other agents) to steer cities in particular directions is not conceptualised as a characteristic of "the state" or "cities" as a whole. Stone $(2005,2013)$ alerts us to the fact that it might be more useful to look at parts of the state, sectors or areas of the city, at specific moments or under specific urban regimes, to interrogate the capacity to govern. This idea is also explicitly raised by Borraz and Le Galès who wish to explore, beyond the classic "who governs" question:

"Do governments always govern? What do they govern, and how? What is not governed? [...] Some activities of government take place routinely, such as raising taxes, planning and caring for specific groups. However, most government activities are not continuous. What is governed is a key question and it may change over time. [...] Some sectors are heavily governed with dense public policies and laws. By contrast, other sectors are not governed at all or weakly governed." (Borraz \& Le Galès, 2010: 2-3)

It is useful to reframe the question of urban governability away from a categorisation of a city as a whole (where specific cities would be more ungovernable than others), and away from an assessment of the state as an object (where certain states would be "failed" whilst other more successful). Urban governability is rather to be approached through the study of defined sectors of intervention, specific areas in cities, or bounded sections of the state, at particular moments in time, and with various degrees of "government" (steering) effort, focus and capacity. This specific understanding of governability might help us progress in that field, more than generic and too abstract debates on city ungovernability as a whole. Questioning ungovernability through the question of street trading government in post-apartheid Johannesburg, means looking for the difference that leadership made (Stone, 2005) in a specific sector, space and time: what were state officials' choices, decisions, non-decisions and their effects on street trading in the city - without assuming that these choices were able to shape society on their own. The double dimension of governability stressed by Kooiman ("the system to govern", interrogating state's capacity to govern, and "the system to be governed", analysing the capacity of society to resist being governed) is to be kept in mind. However, whilst most narratives focus on the second (and it particular City officials when they stress how "ungovernable" street traders are to justify Operation Clean Sweep), this paper's particular interest is on the first, understudied dimension - how specific choices made by state agents or institutions have jeopardised its own ability to govern.

\subsection{Reconceptualising the state to excavate policy objectives}

How to understand and analyse policy objectives, in the era of urban governance where state and non-state agents intervene, to different extents, in policy formulation and implementation; where the state is increasingly (and legitimately) understood as a complex and heterogeneous institution marked by powerful centrifugal dynamics, inconsistent interventions in space and time, with a degree of unexpected, unintended and arbitrary outcomes on contemporary societies; and where 
the state apparatus, penetrated by complex institutional and political logics, remains incredibly opaque to citizens and to researchers?

Taking stock of state's heterogeneity (Das and Poole, 2004; Bierschenk and Olivier de Sardan, 2007; Gupta, 2012) is not sufficient to define the contemporary state. Sets of heterogeneous state departments and agencies might not constitute a consistent "system" (other than in the gaze of its officials and the "citizens" defined by its interventions), but they are nevertheless marked by constant and recurrent attempts by political and bureaucratic leadership to reassert authority, control and unity upon them. The state could be better understood as the permanent tension between leadership attempts to reassert control and unity, and the centrifugal forces of a complex set of departments and agencies seeking autonomy.

These processes of construction of unity and consistency of "the state", are ad hoc and temporary. They are highly focused on specific sections of the state, sectors of policy intervention, spatial areas in the city, and at particular moments. They depend on political contexts: a political priority important to flag, the urgent need to provide a unified and visible state response to a crisis, in a specific geographic area or policy sector, often singled out by a social mobilisation, litigation, natural disaster, or violent conflict. What is framed as a "public issue" in a contextualised political agenda might determine where state leadership will scrutinise its own machinery and attempt to build consistency, for a certain time at least. In this understanding, the "ungoverned" or "less governed" areas or sectors interrogated by Borraz and Le Galès (2010) might be those that are not framed as public issues, not deemed worthy (in political terms) of fostering state unification efforts.

Beyond the chronic rivalry between the political and administrative arms of local government (Lodge \& Wegrich, 2012), the heterogeneity between different departments within a City, with their specific mandates, officials' skills and professional training, is a classic in public administration literature. Literature conceptualising state unification efforts (rather than assuming unity) in this context is more elusive, but inspiring. Jones (1995) argues, for instance, that it is hardly surprising if legal, finance or economic departments, are focused on attracting investment and promoting businessfriendly policies, whilst community services, welfare or housing departments are pushing for redistributive policies. In a different perspective, Bourdieu speaks of the "right" and the "left hand" of the state (1993), the latter focusing on social functions trying to compensate the most brutal effects of market logics, that are simultaneously supported by the right hand of the state (embedded in its economic, budget, police and justice departments). For Bourdieu, in a neoliberalising era, the left hand of the state is becoming powerless and increasingly compelled to service the right hand which is given higher importance, budget and political prominence. For Jones (1995), this dichotomy is less contextual, more essential to the state: unity in state intervention is to be constructed by strong leadership at the top municipal level, which can mitigate the logical professional and functional inclination of each department and create consistency and drive in municipal interventions.

This emphasis on leadership (mayor and his team), essential to overcome the heterogeneous nature of the local state in order to govern, in specific areas of interventions and in specific times and contexts, is empirically confirmed by the North American literature on "Activists in City Hall" (Clavel, 2010; Gendron and Domhoff, 2009), and a number of testimonies of activist planners pushing for specific redistributive or transformative agendas, in North American cities after the civil rights movement (Krumholz \& Clavel, 1994). Difficult to generalise or to theorise, these testimonies nevertheless showcase in a high level of details the work of building coalitions, framing internal and external alliances, navigating Council politics, side-lining hostile or obstructive departments, institutionalising instruments or adopting informal practices in the pursuit of specific policy goals. These goals are reframed and reshaped by a team of officials with strong (mayoral) political support, according to opportunities and constraints, but nevertheless readable under a broad policy direction 
or objective. This set of work certainly argues for the interest and relevance of research on the internal dynamics of the local state in building urban policies, their instruments and institutions.

The possibility for direct observation of state practices however remains exceptional. It is often based on officials-turned-academics (or vice versa), or on specific work capturing and contextualising officials' testimonies and reflexions on their own practices ${ }^{5}$. Debates have raged in implementation studies about the benefits and shortcomings of both top-down and bottom-up approaches of policymaking (Winter, 2006): the former focusing on policy documents and officials' discourses, the latter analysing state practices from policy recipients' experiences. These debates have given rise to interesting developments around the analysis of "policy instruments" as another way to interrogate the politics of policy-making, but also the construction of policy goals (Vedung, 1998; Winter, 2006). Such an analysis is also relevant in contexts where public policy documents arguably lose their relevance and meaning, and possibly their ability to give real direction to state practices. As argued by Lascoumes and Le Galès (2007: 18),

"Policy instruments are very effective indicators to understand and trace policy change over time [...]. In a political context where ideological vagueness seems to prevail [...], the view can be taken that it is now through public policy instruments that shared representations stabilize around social issues."

The "ideological vagueness" of policy discourse is particularly prevalent in the case study at stake, the government of street trading in post-apartheid Johannesburg. The vagueness of policy is indeed the point of departure of this paper, where the policy rhetoric of inclusivity stands at odds with the everyday, restrictive ${ }^{6}$ government of the sector. This gap has been described as municipal inconsistency (Dinath \& Zack, 2014), municipal double agenda (Pezzano, 2016), policyimplementation gap (Matjomane, 2013); and the crisis of Operation Clean Sweep could be read as the explosive manifestation of this gap. In this context, however, I argue that public policy documents are only the tip of the iceberg, or rather a thin veneer of progressive discourse masking more consistent and powerful policy instruments, focused on restricting street trading in Johannesburg inner city. An emphasis on public policy documents (more available to the public) and an analysis in terms of "policy implementation gap" can only lead to the conclusion of inconsistency and possibly ungovernability of street traders (as "society to be governed" that would resist any effort of regulation let alone direction). In this view, good policy intentions would be inevitably pushed aside by intractable difficulties in implementation or in the resistance of society. Analysing a set of various policy instruments (internal policy guidelines, ad hoc agreements with business coalitions, institutions dedicated or involved in the management of street trading, technical tools such trader databases and maps), casts the light on ungovernability of the "system to govern" rather than of the "system to be governed", and demonstrates how municipal choices and non-choices are first producing informality in the state, and in several instances have deprived the state from its capacity to govern, in other words to steer.

\section{Municipal choices of policy instruments to govern street trading in post-apartheid Johannesburg}

This section aims at going beyond the "policy implementation gap", by looking at how a set of policy instruments shape the way street trading is governed in Johannesburg. It first argues that the increasingly progressive street trading policy has not significantly reshaped municipal institutions and other key policy instruments, still framed to restrict and sometimes to ban street trading from the inner city. A second step questions the permanence of this contradiction (between the progressive public policy statements and the restrictive policy instruments), explores how it can be understood, and argues that the contradiction simultaneously fulfils specific functions for the state, and weakens its capacity to govern. 


\subsection{Progressive public policy, denialist institutions, restrictive tools to (not) govern street trading}

Since the mid-2000s, a progressive public rhetoric has developed in contrast to previous street trading policy, acknowledging the permanence and importance of street trading in Johannesburg (Matjomane, 2013). The 2007 Informal Trading policy, as well as the revised 2009 Informal Trading By-Laws, recognise the contribution of the informal economy to job creation and poverty alleviation. The 2007 policy introduces sections on the training and mentorship of traders, support for business incubation and cooperative formation, and consultation (CoJ 2007: 14, 15, 17). The 2009 by-laws even mentions the constitutional "freedom to engage in informal trading" (CoJ2009: 4). This acknowledgement is echoed and deepened in a number of other public policy documents elaborated through public participatory processes, such as the 2006 and later the 2011 Johannesburg Growth and Development Strategies, the 2007 Inner City Regeneration Charter and the 2013 Inner City Road Map.

However, all other policy instruments, more technical, and generally not submitted to broad public debates, still strongly express the City of Johannesburg's objective to severely restrict street trading from its inner city, if not ban it altogether. Some of these instruments were inherited from the late 1990s- early 2000s, where the restrictive approach was explicit and unashamed, and grounded in the vision of having all street traders relocated into markets. These instruments were not adjusted nor reformed after the public policy shift. A second set of instruments were set up post-2007, and are less explicit in their restrictive direction, but nevertheless do not challenge the restrictive approach embedded in the first, and often rather consolidate it.

Space is lacking here to present the nature, articulation and genealogy of all these instruments, as part of a "system to govern" (this is done elsewhere in a paper dedicated to their study: Author, in press). I will only mention briefly a few of these instruments, to illuminate the consistency, and persistency, of a repressive municipal approach to street trading, in spite of a public rhetoric stating the opposite.

Since the late 1990s, street trading has been managed by a specific institution, the Metropolitan Trading Company (MTC), a municipality-owned entity set up during the broad restructuring of the City administration along new public management lines. MTC was a semi-autonomous, business-like, operational arm of the City Department of Economic Department (DED) (at the time called Economic Development Unit), whose focus was on steering and giving strategic direction to urban economic development. MTC was explicitly geared towards the management of markets and taxi ranks, and was supposed to derive its income from charging rent from traders and taxi owners. Street trading was not mentioned in MTC's mandate at the time of its creation: the public objective was still to relocate all street traders into markets, where the provision of services and infrastructure was clearly easier, and markets were also supposed to assist in containing traders into earmarked spaces, not infringing, it was hoped, on congested streets. Street traders, who were not supposed to exist anymore in the short term, were not considered worth developing dedicated institutional resources and management instruments.

MTC's mandate however did not change post-2007, after public policy documents embraced the permanence of street trading: MTC was still focused on the management of markets, not mentioning the management of streets or of pavement traders. This denialism was confirmed by the transfer, in 2013, of MTC's functions to the Johannesburg Property Company (JPC), the municipal entity in charge of managing municipal assets (land, property and in this case markets). This decision, made by decision of Mayor Tau against the advice of MTC and other City senior officials (who understood the gap between MTC's official mandate and its operational needs), further emphasised the central municipal focus on the market infrastructure, whilst the management of street and traders was left in a limbo ${ }^{7}$. 
Further testimony to the essentially restrictive nature of municipal objectives towards street trading, the Johannesburg Metropolitan Police Department (JMPD) remained the dominant institution dealing with street trading on an everyday basis. Developmental programmes leave the way to bylaw enforcement as the key policy instrument - and the municipal police becomes the de facto, everyday manager of the streets, alternatively tolerating unauthorised encroachment (through negotiations that can involve bribery), and impounding goods or using violence against unauthorised traders. This practice is far from being unique to South African cities, and the central role of the local police in the management of street trading - involving cycles of violence and corruption as everyday arrangement - is dominant in most cities of the world (Anjaria, 2011; Kamete 2013; Author, in press). But perhaps it was not to be expected in cities which have adopted more progressive policies, and as the shift to a post-apartheid regime in South Africa had led to the core function of managing street traders supposedly shifting from the police to a business development unit within municipalities (Skinner, 2000). It is at this level however that street trading government is failing the most visibly: property owners and businesses on the one hand, traders on the other blame the police as inefficient, corrupt and violent - the former calling for stronger by-law enforcement, the latter denouncing human right or legal abuses.

A third instrument showcasing the real state objective (restricting street trading in the inner city), is an opaque politics of numbers and mapping, left off the radar of most policy documents and discourses, as well as, strangely enough, of scholarly analyses on the governance of street trading. This could fall under what Ananya Roy (2009) has called a "politics of un-mapping" - the deliberate opacification of information and knowledge in certain sectors of intervention or areas in the city. Keith Breckenridge has termed it "no will to know" in state bureaucracies (2012) (and we could name it here the "will not to know") - where processes of enumeration and registration have deliberately not occurred for certain groups or areas, as a logic of containment was deemed sufficient to exert minimum control, whilst (costly) processes of registration were reserved for the population groups that were to benefit from state's attention. This is also what is empirically illustrated by Aguilera (2012), when he investigates how slum-dwellers are enumerated in databases in European cities and how the municipal lack of will to count this group is linked to its reluctance to intervene: for the state to count slum-dwellers would mean to accept responsibility for this group, consolidate it as a "public issue" that would then demand resources and targeted intervention.

The story of figures and mapping of street traders in Johannesburg inner city sounds very similar. What is striking in Johannesburg is the absence of census of existing traders, and of maps on their localization in the inner city. The latest officially published figures date 2001, where about 10000 traders were counted in the inner city ${ }^{8}$. In 2008 a census was made by the DED-MTC for inner city traders, inaccessible to the public: officials quote figures for other regions but never for the region $\mathrm{F}$ which covers the inner city, or resort to percentages so as to avoid providing numbers (Figure 1).

Figure 1 - Municipal graph as tools of (non) communication: not showing number of street traders in inner city Johannesburg 


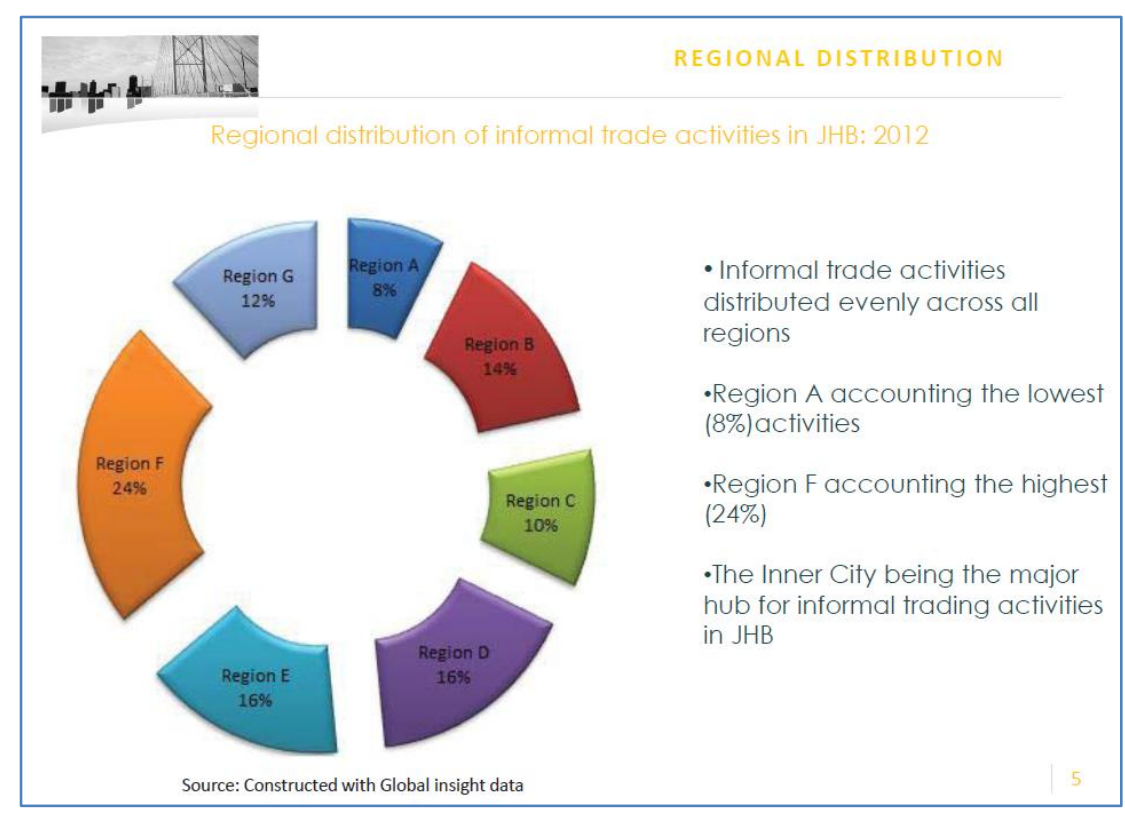

Source: Document presented in a public participatory meeting, to revise the inner city informal trading plan (DED 2016a)

A consultants' report for MTC (Muhle, 2008) mentions a baseline survey of informal traders conducted for MTC that estimates the number of street traders in the inner city at about 7000 in 2008. DED (Figure 1) mentions a 2012 survey carried by a consultant, but does not disclose numbers. This number of traders is never released in public documents or engagements. Stakeholders (academics, business and traders), in several rounds of participatory processes on street trading governance, have called for a census as a starting point for the debate (what is the scope of the issue, what are the needs, how many traders are concerned), to no avail ${ }^{9}$ : officials' responses are always to stick to the number of "legal traders" (2700), as the traders they would consider in their plan, arguing the (undefined) rest would be dealt with through law-enforcement.

In parallel to these opaque and often outdated censuses, the 2007 Informal Trading Policy laid the basis for the creation of a database of (authorised) street traders, who were to be provided with smart cards that would record their profile, status, goods sold, location (that was to be administered by MTC). The rollout of the smart cards was however interrupted, and the mass of unauthorised traders created incentives for a black market to the point the database was considered utterly inaccurate. It is one of the reasons advanced by officials to justify Operation Clean Sweep ${ }^{10}$, as the process entailed a screening of all traders, only those considered legitimate being allowed to get back to their trading stall after verification of their documents and rectification of the database. The trader database was considered "corrupt" and no longer efficient as a management tool: only a "blitz" (brutal, once-off and massive police intervention) could possibly reset the trading landscape, since traditional policy instruments had shown their inefficiency. This blitz strategy however failed dismally.

Yet officials keep referring to numbers of existing traders in order to justify their practices. The modernist argument, repeatedly advanced in internal documents and public meetings, asserts that the "street carrying capacity" for trading is being "exceeded" (CoJ, 2014); streets are being "invaded", and pavement trader numbers ought to be reduced drastically, along "scientific, technical and rational" criteria. Yet there is no clarity on what this "street carrying capacity" means, how it is defined, how it could be debated. And the number of planned authorised trading sites has been shifting in time, in response to political contexts: 2300 in 2012, 1500 during Operation Clean Sweep (CoJ, 2013), 7000 after the municipal defeat in Court, 4500 as planned in the latest policy draft document (2016). This arbitrary figure could not illustrate better the political nature of the definition of informality stressed by Roy (2005) - by shrinking or expanding the number of authorised street 
traders, the state simultaneously expands and shrinks the extent of informality, and the number of unauthorised street traders.

Furthermore, there is no municipal map or plan of trading spaces (authorised and/or existing), at least until very recently. A 1998 Council resolution listed the areas in which street trading would be prohibited (GJMC, 1998) - almost the entirety of the inner city. But a map of existing and intended demarcated sites for trading was never produced or circulated to the public, nor to the traders. Since 2016 however, in response to the Constitutional Court judgement, the municipality decided to produce an inner city trading map, submitted to public comment. The City needed to demonstrate to the court that it was interacting with traders; hence it started a loose series of participatory workshops throughout 2015 and 2016 around a new trading plan (presented as PowerPoint slides) and a new trading map. What was clear in the meetings however, was a degree of dis-ingenuity from City officials, and the impossibility in these engagements to lift any of the ambiguities shaping the documents at stake. The trading map presented for discussion was for instance disconnected from figures: streets are indicated as open to street trading but the number of authorised trading sites per street remains undisclosed or undecided - to the disarray of existing traders on each street, not ensured that authorised trading in their street would mean their inclusion or not.

INSERT HERE: Figure 2 - Mapping authorised street trading in Johannesburg inner city - a recent exercise

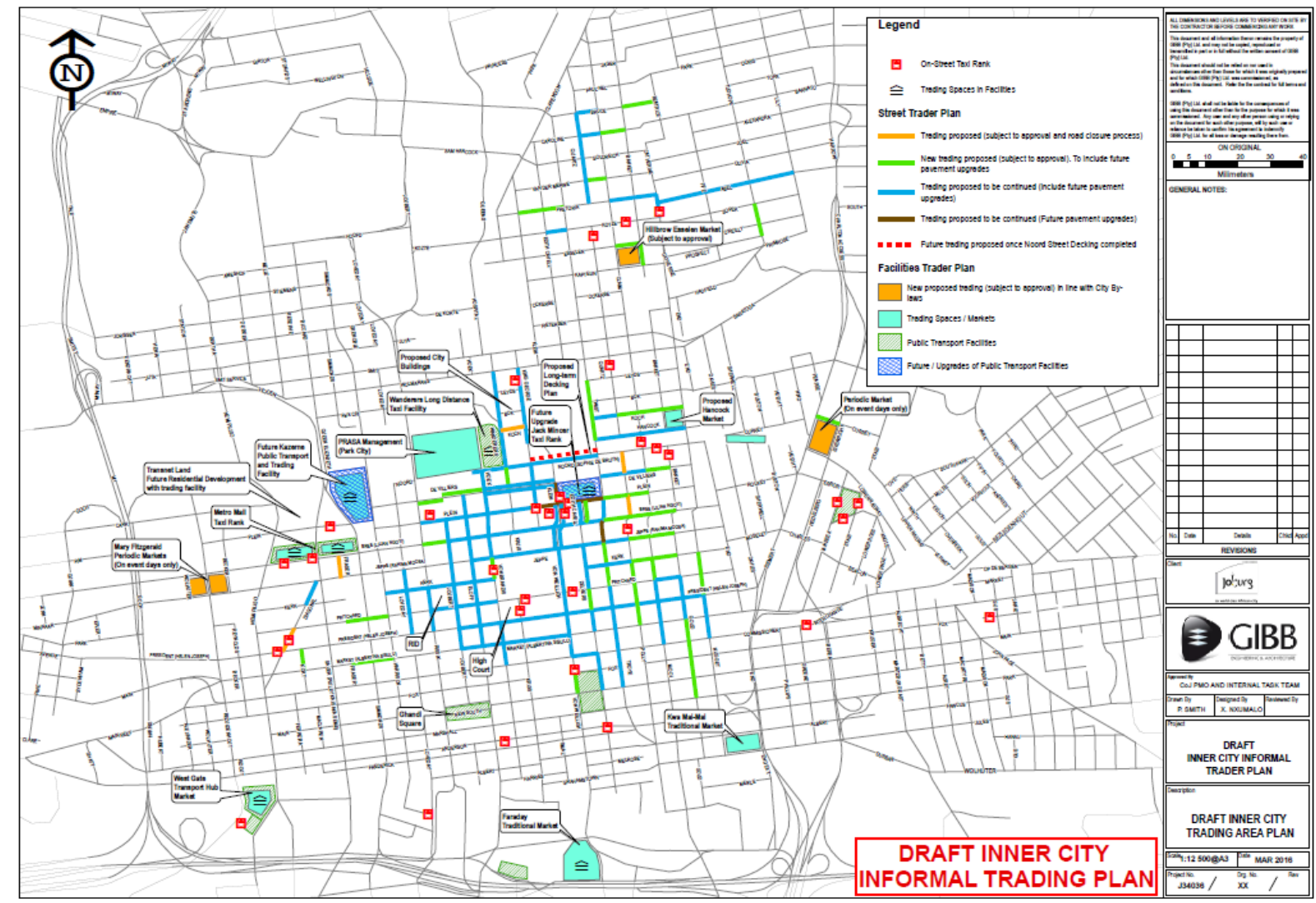

Source: DED 2016b

The 2016 mapping process provides a bit more clarity to traders as to which streets are open for trading, but does not necessarily mean there is a genuine shift away from the restrictive approach. In particular it does not does not question the 1998 Council resolution (GJMC, 1998), forbidding most of the inner city spaces to street trading: therefore, only a minority of streets is concerned by the mapping, and the overall ban on street trading in most of the inner city is excluded from public scrutiny and debate (Figure 2). In the same ambiguous vein, the 2016 trading plan asserts its choice 
to "expand authorised trading sites" and announces the figure of 4500 legal trading sites to be made available in the (undefined) medium term (DED, 2016b). But (besides not re-opening "new" streets for trading), confusion is carefully maintained around what "authorised trading sites" mean, as the official number includes market and building trading sites, aggregated to the street trading sites (under the misleading term, adopted by the City, of "informal" rather than "street" or "pavement" trading sites). This work of confusion can efficiently mask the probable continuation of street trading restriction - where street traders are still intended to be relocated from pavement to buildings and markets.

This shift towards finally mapping authorised street trading sites is therefore unlikely to mark a shift away from the municipal restrictive practice, or an alignment with the public rhetoric embracing street trading in the City. It can more convincingly be understood as a practical (some may say, cynical) way of responding to the Constitutional court case after Operation Clean Sweep. By promulgating rather than restricting trading spaces (adopting a "positive" not "negative" approach), the municipality is able to escape the (trader-friendly) 1991 Businesses Act, which was at the core of the 2014 Constitutional judgment against the City, and subjects any restriction of trading spaces to intense negotiations with existing traders: a negotiation that the City wants to avoid at all cost. The City is actually adopting this "paradigm shift" to avoid falling under what is considers impractical and cumbersome sections of the Businesses Act, as explicitly presented in public meetings:

The next step in terms of [the 1991 Business Act] Section S6A(2)(b) would be to request Council to declare a motion to restrict or prohibit trading which plan would be advertised for 21 days. However, [...] there is no need for the City to prohibit trading in areas already designated.

The Businesses Act Paradigm Shift -S6A(3)(b) Demarcation of Trading Areas. This section allows the City to "set apart and demarcate stands or areas for the purposes of the carrying on of the business of street vendor [...]". It must be remembered that this section does not have the strict requirements set out in $\operatorname{S6A}(2)(c)[\ldots]$. As there will be no restriction or prohibition during this stage, there is no requirement for a plan to be advertised as was required in terms of S6A(2)(e) of the Act." (Extract from the slides presented by DED in a public meeting with traders: DED 2016b)

\subsection{How to understand the (persistent) contradiction between progressive public policy and restrictive set of policy instruments?}

Rather than illustrating the difficulty in implementing a progressive policy taken as the true reflection of state's objectives, the convergence of most policy instruments towards a restrictive approach questions the sincerity, the validity and the function of the public policy documents, that are not reflecting any genuine or deep municipal commitment to support and enhance street traders' economic activity. How to understand the contradiction between these instruments, and what are its effects in terms of the capacity of the state to govern street trading?

It is important to go back to the genealogy of the street trading public policy that has marked the mid-2000s in the city of Johannesburg, towards acknowledging and embracing street trading as a permanent feature of South African cities, and as a key sector to alleviate poverty and unemployment. This shift was driven by a specific unit in the City of Johannesburg, the Central Strategic Unit (CSU), an advisory unit to Mayor Masondo, peopled at the time by a cohesive group of former anti-apartheid activists and progressive thinkers. Before the 2006 local elections, the CSU worked to convince the Mayor to adopt a more pro-poor vision, for his second mayoral mandate (2006-2011), in response to increased contestation from the broader society: protests but also litigation where the City often lost its cases (inner city evictions, water cut-offs). This contestation was damaging for the City's and the Mayor's image, whilst litigation was seriously curtailing its ability to intervene in the inner city. CSU officials worked through the 2006 Growth and Development Strategy to embed new principles in the Mayor's rhetoric, such as the "Proactive absorption of the poor" as one of the six key principles of the City strategy (CoJ 2006). The GDS was then presented and explained in each City department, and each of them had to align its objectives and policies to 
these new principles ${ }^{11}$. This department, and the progressive consultants it hired to facilitate public participatory processes, were also involved in the other public policy documents (such as the Inner City Charter and later the Roadmap), along similar lines. One cannot doubt the consistency and sincerity of the progressive policy objectives embedded in these documents - attempting to influence and redirect existing municipal practices towards including rather than excluding the poor in the inner city.

Why is it then that these progressive principles embracing the permanence of street trading in the city, failed to trickle down, beyond reshaping the public policy documents in the Department of Economic Development? It is not enough to blame the inertia of bureaucracy and existing institutions and tools of intervention - as clearly leadership and resources were not forthcoming to reshape the municipal approach to street trading beyond a public policy document alignment. There was no official championing this shift in the approach in the Department of Economic Development or at the mayoral level. It might be that the shift was accepted half-heartedly by the Mayors, and not followed by redirecting human and financial resources to implement it. As a matter of fact, both Mayor Masondo (2000-2011) and Mayor Tau (2011-2016) have had a keen interest in the inner city and its regeneration - and (unmanaged) street traders were seen as nuisance within both their vision. One can decipher therein, through their public discourses and informal reactions to trader contestation, a strong antipathy towards inner city street trading, for perhaps different reasons. There is a dislike of disorder and the importance of promoting a sense of "dignity", in "decent" work conditions, for the former; and a sensitivity to global investment and business interests, joint perhaps with a xenophobic tint to his politics (in the context of declining support for the ANC in the metropolitan region), for the latter. Whilst this antipathy was clear for both mayors, it might have been embarrassing, and politically ill-advised, to embed it explicitly into policy documents. On the contrary, this paper argues that it perhaps proved convenient to embrace restrictive objectives under the shield of a progressive policy veneer - as an unintended consequence of the failed reform, driven mostly by one department (the CSU, critical under Masondo, marginalised by Mayor Tau) but not backed up by political leadership in its reform drive. The "policy-implementation gap" therefore does not derive from a strong policy direction failing to be executed by a reluctant or complex administration; but rather from a weak attempt to redirect policy from one fragment of the state, not backed by political leadership, and not having sufficient political support to unify and steer heterogeneous state practices in one consistent, reformed approach.

Furthermore, the persistence of this contradiction (between policy directions and other policy instruments over more than a decade), and the municipal reluctance to amend and correct the set of policy instruments dedicated to street trading management (manifest in institutional and practical continuities, and obvious in the many public engagement processes unfolding since the 2010s), indicate that the contradiction is not damaging for the state. Perhaps more, it arguably serves a function, fulfils some goals, for sections of the state, and is purposefully kept as contradiction in spite of its (other) shortcomings.

Are progressive public policies an impediment to restrictive objectives, and is the gap between public policy and the other instruments, an issue for the City? Not directly: those public policy documents are relatively toothless, as contrasted with the 1991 National Businesses Act, that was mobilised to protect traders after Operation Clean Sweep.

Are these progressive policies useful for the mayoral restrictive objectives? They are: perhaps accidentally, but efficiently in practice. It seems public policies have become necessary public relation instruments, both with international players (applauding the alignment of Johannesburg's vision with global trends advocating the informal sector as a means to poverty alleviation); and with local stakeholders, for whom it is more difficult to debate and contest what remain implicit (restrictive) policy objectives, under the mask of a progressive public policy discourse. It is indeed virtually impossible for trader organisations to challenge technical, internal documents in the City not 
circulated to the public; or to try and change institutions, tools and behaviours that are impacting on the ground but not framed in any document, and moreover disjointed between various departments and agencies (DED, MTC-JPC, JMPD). Public and legal contestations from traders have only targeted police behaviour (abusive confiscation, corruptive practices), as the face of the state on the ground with relatively clear responsibilities - a less fragmented section of the state ${ }^{12}$. It is only during Operation Clean Sweep, where politicians as City representatives have taken a clear public stance against street trading, that traders have been able to collectively and formally challenge the City, with success.

Furthermore, the "politics of un-mapping" have also a clear function in protecting the state from the responsibility of providing trading sites or other job opportunities for the traders it excludes from the inner city through its restrictive policy. The State's "will not to know", its resistance to publicise and communicate numbers of existing traders, to conduct censuses and reflect on the scope of the issue it is supposed to govern, is explicitly linked to a strategy of avoidance: enumerating would create a category that could demand that the state, depriving traders of the possibility to create their own jobs, should provide alternative employment opportunities. In practice, it is an issue that often emerges in participatory forum from trader leaders, and that the officials carefully avoid debating ${ }^{13}$. In theory, it is a classic politics of non-recognition protecting the state from having to provide benefits to certain population groups.

Contradiction as informal practice of the state, un-mapping as policy tool, are here confirming Roy's argument around the "idiom of urbanization" of Indian cities: a strategic (if not necessarily intentional) way for the state to plan its cities flexibly, shielded from a number of constraints including a degree of democratic accountability and public scrutiny, and the need to provide alternatives when destroying livelihoods through its interventions. So, on the one hand, this persistent contradiction assists the state in governing street trading, and to maintain its objective of severely restricting street trading. On the other hand however, the implicit nature of municipal restrictive objectives does create an overall ungovernability of street trading.

\subsection{Ungovernability: resistance of the governed or self-incapacitation of the governing?}

Here, it is necessary to pause: is it the informal practices of the state (contradictory policy instruments, denialist institutions not geared to manage the street traders, politics of un-mapping), or is it the restrictive objective itself, that creates ungovernability of street trading? Framed in a slightly different way: is it the City that is "not governing" (not deploying capacity nor instruments to steer street trading), or is it street traders who are "ungovernable" (resisting to being governed)?

The restrictive nature of the municipal approach is certainly fostering resistance of the traders to being governed - which means here, excluded from the inner city. Exclusion of traders from specific spaces can work, at least for some time - as it is the case in the smaller city centre of the more segregated Cape Town, where street trader numbers have been effectively restricted, space is managed through resourced City Improvement Districts (CIDs), a minority of traders is contained into small inner city craft markets whilst a majority has been pushed away in segregated townships (Morange, 2015). To some extent, sections of the Johannesburg inner city (especially those governed by CIDs, with funded and dedicated security guards) are succeeding in protecting "trading-free" pavements and public spaces. But banning street trading is probably doomed to fail overall in large metropolitan areas such as Johannesburg, with its large, desegregated and vibrant inner city (Zack, 2014) - as it is now broadly accepted that informal settlements are inevitable as a response to the housing crisis in cities of the South.

Traders' resistance to being governed has been described through their dominant politics of "quiet encroachment" (Bayat, 1997; Kamete, 2013), or to rising politics of overt confrontation, more or less 
continuous and structured (Lindell, 2010; Author, 2016). The production of a mass of "illegalised" street traders leads to other forms of ungovernability: unauthorised traders cannot be managed, or disciplined: they do not pay rent, they have little incentive to participate in cleaning and regulating their environment, they generally trade in prohibited areas, often in (unfair) competition with authorised traders. In turn, licensed traders start refusing to pay rent or clean the pavement, as they see neighbouring traders not adhering to these rules; market traders having been relocated from the streets, start setting up street stalls again, as they see other street traders take occupation of the space they have been evicted from.

The vision of traders resisting (restrictive) municipal management efforts has done a lot to create the image of "ungovernable street traders" - a positive representation at times (ungovernability as resistance: Bayat, 1997), but mostly a negative one ("an intractable issue" that it is not worth putting policy efforts or resources into). However, it is important to stress that if street traders are resisting their exclusion, they are not resisting being governed, and are not per se ungovernable; most are claiming, even demanding municipal intervention to manage the streets: to secure trading rights to limit harassment, set up conflict or competition management mechanisms, limit street congestion and litter that is also detrimental to their business, coordinate cleaning and waste collection efforts, with a possible participation of traders themselves (Author, 2016). Most are engaged in a politics of recognition rather than in a politics of resistance (Wafer, 2014).

Blaming street trading ungovernability onto street traders (resisting government's consistent but implicit objective: restriction) is ultimately only seeing one side of the coin - where no municipal resources were set aside to manage street traders in other ways than by-law enforcements by the police, discrete training support programmes coordinated by the DED, and the un-mandated, unofficial management of street traders within MTC.

This paper argues that choices made by the municipality have in themselves manufactured the ungovernability of street trading, in the sense of the inability of the City to steer this sector of municipal intervention. These choices have prevented the emergence of street trading as a public issue, by demobilising traders and the broader society through the shield of progressive but superficial rhetoric, the inexistence of dedicated institution that could be engaged, a politics of unmapping that renders invisible the scope of the issue. It has been efficient politically for the state to some extent, as the restrictive nature of the municipal objective has not been identified nor challenged by civil society (besides short episodes like Operation Clean Sweep, presented as ruptures rather than continuities). But the restrictive objective is chronically failing: streets in many parts of the inner city are ultimately congested, littered, and conflict-ridden; a mass of illegalised traders has been created, that cannot be managed; authorised traders lack a dedicated institution to engage with; institutions have no reliable databases to efficiently govern. Whilst it has probably discouraged some would-be traders to set up a business in the inner city streets out of fear of harassment, it has also led to most traders being un-registered, not paying rent, and often not complying with other bylaws. The municipal restrictive objective has also limited street traders' capacity to accumulate capital and grow as entrepreneurs, in contradiction with increasingly pressing policy and political agenda (for all political parties, at all levels of the state) to curb unemployment, create jobs and foster small black entrepreneurship. Finally, the absent or weak public debate (that the City has shielded itself from) has deprived the state of the impetus to reform its own practices (Figure 3 ).

Figure 3 - Manufacturing ungovernability - The vicious cycle of street trading mismanagement 


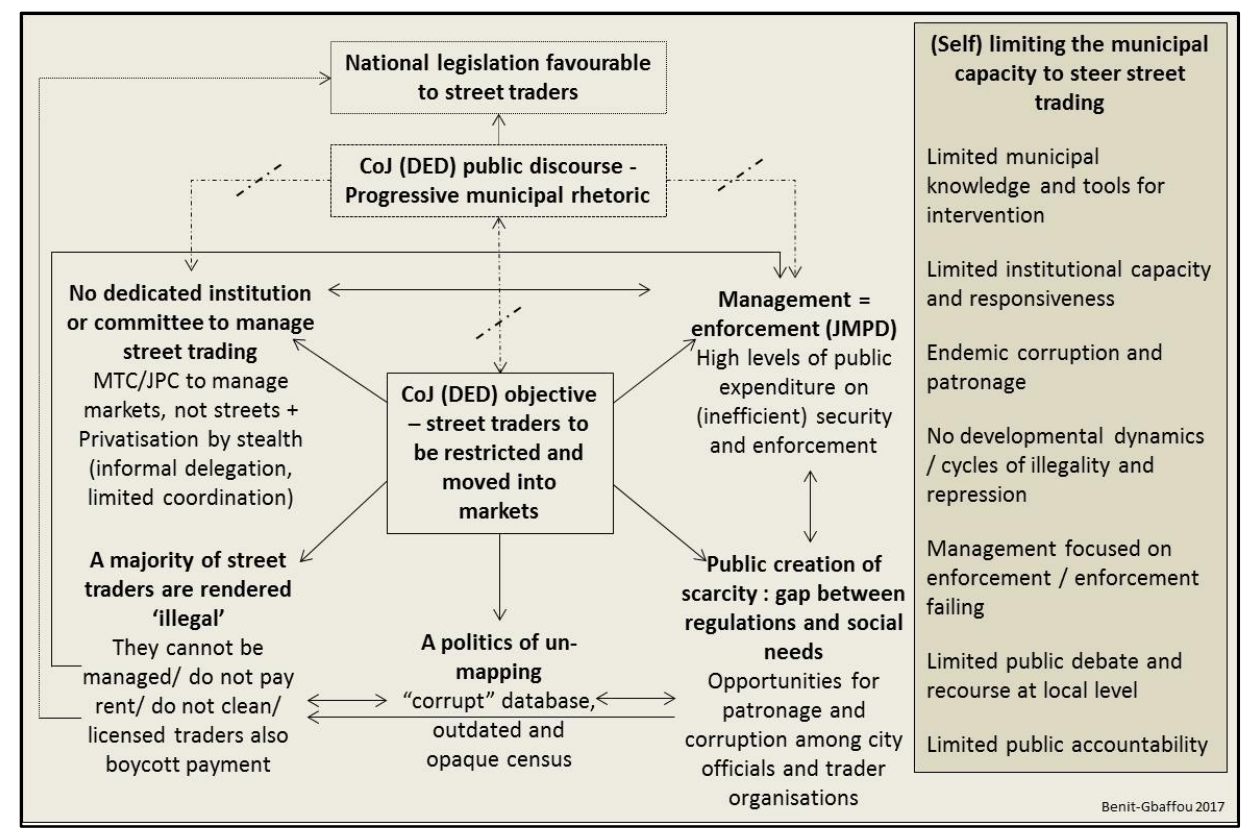

Municipal institutions have developed informal practices to cope practically with the reality of existing traders whose existence they are officially denying, but are ill-equipped to respond to crises, to break the cycle of mismanagement that all stakeholders are denouncing, and to innovate and to experiment, a prerogative that has been captured by selected group of traders and private companies interested in urban management contracts (Author, in press). Their opaque dealings have a degree of everyday functionality but are fundamentally corrupting the state and limiting possibilities for institutional, policy and management reform. These choices of policy instruments have prevented the municipality from taking stock of the severe limitations (including for the City itself) of its restrictive approach, continuously experienced in the last 17 years, and epitomised by the Operation Clean Sweep debacle. Operation Clean Sweep was indeed the expression of a crisis of governability - where the failure of street trading management suddenly became visible to the eyes of the mayoral team, through the sheer mass of the unmanaged, illegalised street traders in the inner city: directly created by denialist and unrealistic targets, but once again blamed on weak enforcement and the "illegal" practices of traders.

\section{Conclusion}

Roy's concept of "informal practices of the state" as "idiom of urbanization" - purposefully used by state institutions as a mode of government of the city, has inspired us to look for ways to unpack the manufacture and dynamics of ungovernability, bringing together classic perspectives on the resistance of the governed, and less classic interrogations on municipal choices of policy instruments and their complex effects on governability. This concept assists us in pursuing Roy's enquiry into "why [municipalities] cannot plan [their] cities", by interrogating more directly the functional or dysfunctional dimensions of municipal choices, including but not restricted to state informal practices. We see state incapacity to govern or to steer street trading through its incapacity to address the failure (or at least, severe limitations) of the restrictive approach to street trading, an incapacity that we argue derives from its own choices. The political shield created by progressive but superficial policies, masking the municipal restrictive objectives, has led to a relatively weak, or at least un-sustained, social awareness on the issue, which in turn fails to exert pressure for the state to focus its attention in "solving the problem" (other than in legalistic and minimal responses). The illadapted policy instruments cannot innovate and experiment other ways of engaging with traders, in spite of interesting pilots constructed at the micro-local level, mostly driven by non-state actors. A full-fledged restrictive drive, as attempted by Operation Clean Sweep, is not legally nor politically, and probably not either practically, sustainable. In this sense, it is municipal decisions that have 
manufactured the ungovernability of street trading: decisions about not unifying the municipal approach and instruments around the revised, more progressive policy; about maintaining and reproducing institutions that have shown their inadequacy to the task, if not their utter denialism of the "issue"; about not considering street trading as a public question worthy of assessment, enumeration, mapping and robust engagement - beyond superficial and divisive, box-ticking public participation exercises.

Rather than "ungoverned", it might be actually more relevant to characterise street trading as an area that is "weakly governed", following Borraz and Le Galès (2010) and coming back to our definition of the state as in a constant tension between centrifugal dynamics and unification efforts. Street trading has not been dealt with as a key, strategic area of intervention for the City leadership. It was not considered worthy of an effort of unification (alignment of policies and policy instruments, resourcing of adapted and dedicated institutions, coordination beyond fragmented departments, effort to assess existing needs and frame policies accordingly) - be it in the direction of implementing restriction through the use of sustained force and surveillance (probably an impossible task in a democratic society), or towards pragmatically reforming policy objectives and instruments towards more inclusive and realistic accommodation of existing traders. The issue of street trading only became a "public issue" (requiring urgent mayoral intervention, focalising media attention, collective mobilization and political campaigns), during the short moment of crisis provoked by the City illadvised Operation Clean Sweep. Outside of this short moment, and still today, street trading remains rather "weakly governed", "managed" rather than steered - in inefficient and disempowering (for both traders and state) but relatively quiet ways.

The case of the government of street trading in Johannesburg illustrates the importance of unpacking state practices, cast in broader debates about urban ungovernability particularly prevalent in the case of dense, diverse, informalising inner city centres in cities of the South. The approach through policy instruments has allowed going beyond explanations in terms of "policy-implementation gap", which tend to celebrate political directions that would be lost in the complexity of an obscure, malevolent or arbitrary state machinery (Gupta, 2014). Our analysis is an opposite one, highlighting rather the continuity and relative consistency and power of policy instruments towards restricting street trading in inner city Johannesburg, not aligned to relatively superficial public policies, that did not succeed in reforming policy instruments (official guidelines, tools, institutions, practices), due in particular to limited mayoral support and leadership. It is from this consistency and continuity that we derive a sense of the real policy objectives, rather than from policy documents that seem to have become meaningless - and in any case unable to steer and guide state practices. Indeed, public policy documents can here no longer be considered as statement of state's policy objectives. They are possibly becoming less meaningful and less powerful in an era of ideological vagueness; paradoxically so in an age of increased public engagement that seem to be leading to negotiations and compromises, but are in fact increasingly disconnected from local politicians' commitments and actions, leading them to develop other sets of policy instruments away from the public gaze.

Conceptualising "governing" as an time-bound direction given to a heterogeneous state apparatus in a set of specific areas of intervention (judged strategic in certain places and times), helps reinvigorating the notion of democratic accountability, without ignoring or underplaying the internal and external complexity of the governing process. It leads to interrogate differently the notion of political leadership in cities, which tends to be downplayed in an era of governance and globalization (Greasley and Stoker, 2008; Borraz and John, 2014). We would like to end this paper by stressing the political leadership's choices and responsibility, in not proactively championing an inclusive postapartheid inner city in Johannesburg, in particular in the critical field of (informal) livelihoods and economic activities; in not giving public policies framed by the progressive elements in their strategic teams and by various modes of engagement with the broader public, sufficient substance, credibility, and follow-up to challenge and shape conservative municipal visions, institutions and practices. 


\section{References}

Aguilera, T. (2012). The Hypothesis of Ungovernability of Societies. A Critical Response from the example of Urban Policies facing slums in Paris and Madrid. Paper presented at the IPSA Annual Conference, Madrid, Spain.

Anjaria, S. (2011). Ordinary State: Everyday corruption and the politics of space in Mumbai. American Ethnologist, 38(1), 58-72. doi: 10.1111/j.1548-1425.2010.01292.x.

Author (in press).

Author (2016).

Bayart, J.-F., Ellis, S., \& Hibou, B. (1999). The Criminalisation of the State in Africa. Bloomington, Indiana: Indiana University Press.

Bayat, A. (1997). Uncivil society: the politics of 'informal people'. Third World Quarterly, 18(1), 53-72. doi: 10.1080/01436599715055.

Benjamin, S. (2004). Urban land transformation for pro-poor economies. Geoforum, 35, 177-187. doi: 10.1016/j.geoforum.2003.08.004.

Bierschenk, T. \& Olivier de Sardan, J.-P. (Eds). (2007). States at Work: Dynamics of African Bureaucracies. Leiden: Brill.

Borraz, O., \& John, P. (2004). The Transformation of Urban Political Leadership in Western Europe. International Journal of Urban and Regional Research, 28, 107-120. doi: 10.1111/j.0309-1317.2004.00505.x.

Borraz, O., \& Le Galès, P. (2010). Urban Governance in Europe: The Government of What? Métropoles, 7, 1-14. Retrieved from http://metropoles.revues.org/4297.

Bourdieu, P. (1993). La démission de l'État. In P. Bourdieu (Ed.), La Misère du monde (pp. 219-232). Paris: Seuil.

Bozzoli, B. (1996). From Governability to Ungovernability: Race, class and authority in South Africa's black cities. Seminar Paper presented at the Institute for Advanced Social Research, Johannesburg: Wits University, 18 March.

Breckenridge, K. (2012). No Will to Know: The Rise and Fall of African Civil Registration in Twentieth-Century South Africa. In K. Breckenridge, \& S. Szreter (Eds.), Registration and Recognition. Documenting the Person in World History (pp. 1-38). Oxford: Oxford University Press.

Bruera, H.G. (2013). Lula, the Workers' Party and the Governability Dilemma in Brazil. New York: Routledge.

Chance, K. (2015). "Where there is fire there is politics": Ungovernability and Material Life in Urban South Africa. Cultural Anthropology, 30, 394-423. doi: 10.14506/ca30.3.03.

Chatterjee, P. (2004). The politics of the governed: reflections on popular politics in most of the world. New York: Columbia University Press.

Clark, M. (2014). Informal Trade in Inner-City Johannesburg: Scoping Study. Draft report, prepared for the Socio Economic Rights institute (SERI), Johannesburg.

Clavel, P. (2010). Activists in City Hall. The Progressive Response to the Reagan Era in Boston and Chicago. Cornell: University of Cornell Press.

Das, V. \& Poole, D. (Eds). (2004). Anthropology in the Margins of the State. London: James Currey.

Davis, M. (2007). Planet of Slums. London and NY: Verso.

Dinath, Y. \& Zack, T. (2014) Explaining the Impasse: Why informal economic activity has not been consistently supported by the City. In T. Zack, S. Charlton, P. Harrison \& P. Jenkins (Eds), Alternative Formalities, Transnationalism and Xenophobia in the Inner City of Johannesburg (AFTRAX). Research report prepared by the School of Architecture and Planning, Wits University, for the City of Johannesburg.

Ferman, B. (1985). Governing the Ungovernable City: Political Skill, Leadership, and the Modern Mayor. Philadelphia: Temple University Press.

Ferman, B. (1983). Beating the Odds: Mayoral Leadership and the Acquisition of Power. Review of Policy Research, 3(1), 29-40. doi: 10.1111/j.1541-1338.1983.tb00067.x.

Gendron, R., \& Domhoff, G. W. (2009). The Leftmost City: Power and Progressive Politics in Santa Cruz. Boulder: Westview Press.

Greasley, S., \& Stoker, G. (2008). Mayors and Urban Governance: Developing a Facilitative Leadership Style. Public Administration Review, 68, 722-730. doi: 10.1111/j.1540-6210.2008.00910.x. 
Gordon, I., \& Travers, T. (2010). London: planning the ungovernable city. City, culture and society, 1(2), 49-55. doi: $10.1016 /$ j.ccs.2010.08.005.

Gupta, A. (2012). Red Tape: Bureaucracy, Structural Violence, and Poverty in India. Duke University Press.

Harrison, J., \& Hoyler, M. (2014). Governing the new metropolis. Urban Studies, 51, 2249-2266. doi: 10.1177/0042098013500699.

Heller, P. (2016). The Exclusion Field: Politics, Institutions and Inequality in an Indian City. Working Paper, Brown University, December.

Hibou, B. (2015 [orig. published 2012]). The Bureaucratization of the World in the Neoliberal Era. An International and Comparative Perspective. New York: Palgrave Macmillan.

Holston, J. (2009). Insurgent Citizenship: Disjuncture between Democracy and Modernity. Princeton: Princeton University Press.

Jones, B. (1995). Bureaucrats and Urban Politics: Who controls? Who benefits? In D. Judge, G. Stoker, \& H. Wolman (Eds.), Theories of Urban Politics (pp. 72-95). London: Sage.

Kamete, A.Y. (2013). On handling urban informality in southern Africa. Geografiska Annaler: Series B, Human Geography, 95(1), 17-31. doi: 10.1111/geob.12007.

Kohli, A. (1991). Democracy and Discontent. India's Growing Crisis of Governability. Cambridge: Cambridge University Press.

Kooiman, J. (2008) Exploring the Concept of Governability. Journal of Comparative Policy Analysis: Research and Practice, 10, 171-190. doi: 10.1080/13876980802028107.

Krumholz, N., \& Clavel, P. (1994). Reinventing cities: equity planners tell their stories. Philadelphia: Temple University Press.

Le Galès, P., \& Lorrain, D. (2003). Gouverner les très grandes métropoles? Revue française d'administration publique, 3, 305-317. doi: 10.3917/rfap.107.0305.

Lindell, I. (ed). (2010). Africa's informal workers- Collective agency, alliances and transnational organizing in urban Africa. New York: Zed Books.

Lindell, I. (2008). The Multiple Sites of Urban Governance: Insights from an African City. Urban Studies, 45(9), 1879-1901.

Linder, H., \& Peters, B.G. (1987). A design perspective on policy implementation: the fallacies of misplaced prescription. Policy Studies Review, 6, 459-475. doi: 10.1111/j.1541-1338.1987.tb00761.x.

Lipietz, B. (2004). 'Muddling-through': urban regeneration in Johannesburg's inner city. Paper presented to the N-AERUS annual conference, Barcelona, Spain.

Lodge, M., \& Wegrich, K. (2012). Public administration and executive politics: perennial questions in changing contexts. Public Policy and Administration, 27, 212-229. doi: 10.1177/0952076712438724.

Lund, C. (2006). Twilight Institutions: Public Authority and Local Politics in Africa. Development and Change 37, 685-705. doi: 10.1111/j.1467-7660.2006.00497.x.

Matjomane, M. (2013). Strategies Used by Informal Traders Organisation Leaders to Influence Informal Trading Policy and Implementation. Master thesis, Urban Studies, Johannesburg: Wits University.

Mayntz, R. (1998). New Challenges to Governance Theory. European University Institute, Jean Monnet Chair Paper RSC, ${ }^{\circ}{ }^{98 / 50}$. Retrieved from http://www2.uned.es/113016/docencia/spd\%20-\%20doctorado\%20200102/Introducci \%f3n/Mayntz\%20governance\%20EUI\%201998.htm

Mayntz, R. (2006). Transition to sustainable development: Lessons from governance theory. Paper presented to the International workshop 'Transitions to sustainable development: complexity, co-evolution and governance', KSI, Egmond aan Zee, the Netherlands.

Morange, M. (2015). Participation, neoliberal control and the voices of street traders in Cape Town: a Foucauldian perspective on 'invited spaces'. In Bénit-Gbaffou C. (Ed), Popular Politics in South African Cities. Unpacking Community Participation (pp. 171-196). Pretoria, HSRC Press.

Mosse, D. (2004). Is Good Policy Unimplementable? Reflections on the Ethnography of Aid Policy and Practice. Development and Change, 35, 639-671. doi: 10.1111/j.0012-155X.2004.00374.x.

Pereira, C., \& Orellana, S. (2009). Hybrid Political Institutions and Governability: The Budgetary Process in Brazil. Journal of Politics in Latin America, 1(3), 57-79. Retrieved from https://papers.ssrn.com/sol3/papers.cfm?abstract id=1510371. 
Peters, B. G. (1997). Shouldn't Row, Can't Steer: What's A Government to Do? Public Policy and Administration, 12(2), 51-61. doi: 10.1177/095207679701200205.

Pezzano, A. (2016). "Integration" or "selective incorporation"? The modes of governance in informal trading policy in the inner city of Johannesburg. The Journal of Development Studies,52, 498-513. doi: 10.1080/00220388.2015.1126254.

Recio, R. (2015). Engaging the 'Ungovernable': Urban Informality Issues and Insights for Planning. Journal in Urban and Regional Planning, 2(1), 18-37. Retrieved from http://journals.upd.edu.ph/index.php/19May2014 surp/article/view/4651.

Roy, A. (2009). Why India Cannot Plan Its Cities: Informality, Insurgence, and the Idiom of Urbanization. Planning Theory, 8(1), 76-87. doi: 10.1177/1473095208099299.

Roy, A. (2005). Urban informality: toward an epistemology of planning. , Journal of the American Planning Association, 71, 147-158. doi: 10.1080/01944360508976689.

Scholten, P. (2013). Agenda dynamics and the multi-level governance of intractable policy controversies: the case of migrant integration policies in the Netherlands. Policy Sciences, 46, 217-236. doi: 0.1007/s11077-0129170-x.

Simone, A. (2004). People as infrastructure: Intersecting Fragments in Johannesburg. Public Cultures, 16, 407429. doi: 10.1215/08992363-16-3-407.

Skinner, C. (2000). Getting institutions right? Local government and street trading in four South African Cities. Urban Forum 11(1): 49-71. doi: 10.1007/BF03036831.

Stone, C. (2013). The Empowerment Puzzle: In Pursuit of a New Dimension in Governing the City. Paper presented at the American Political Science Association Annual meeting, Chicago.

Stone, C. (1995). Political Leadership in Urban Politics. In D. Judge, G. Stoker, \& H. Wolman (Eds.), Theories of Urban Politics (pp. 96-116). London: Sage.

Stone, C. (1993). Urban regimes and the capacity to govern: A Political Economy Approach. Journal of Urban Affairs, 15(1), 1-28. doi: 10.1111/j.1467-9906.1993.tb00300.x.

Vedung, E. (1998). Policy instruments: typologies and theories. In M.L. Bemelmans-Videc, R. Rist, \& E. Vedung, (Eds.), Carrots, Sticks, and Sermons: Policy Instruments and Their Evaluation (pp 21-58). New Brunswick and London: Transaction Publishers.

Von Holdt, K. (2013). South Africa: the transition to violent democracy. Review of African Political Economy, 40, 589-604. doi: 10.1080/03056244.2013.854040.

Wafer, A. (2011). Informality, Infrastructure and the State in post-apartheid Johannesburg. PhD diss., Geography. Johannesburg: Wits University.

Weinstein, L. (2008). Mumbai's Development Mafias: Globalization, Organized Crime and Land Development. International Journal of Urban and Regional Research, 32, 22-39. doi: 10.1111/j.1468-2427.2008.00766.x.

Winter, S. (2006). Implementation. In Peters, B. G., \& Pierre, J. (Eds.), Handbook of Public Policy (pp. 151-166). London: Sage Publications.

Yates, D. (1977). The Ungovernable City: The Politics of Urban Problems and Policy Making. Cambridge: The M.I.T. Press.

Yiftachel, O. (2009). Critical theory and 'gray space'. Mobilization of the colonized. City, 13, 240-256. doi: $10.1080 / 13604810902982227$

Zack, T. (2014). 'Jeppe' - where low-end globalisation, ethnic entrepreneurialism and the arrival city meet. Urban Forum 26, 131-150. doi: 10.1007/s12132-014-9245-1.

Zack, T., Charlton, S., Harrison, P. \& Jenkins, P. (Eds), (2015). Alternative Formalities, Transnationalism and Xenophobia in the Inner City of Johannesburg (AFTRAX). Report prepared by the School of Architecture and Planning, Wits University, for the City of Johannesburg.

\section{Documents}

Constitutional Court of South Africa. (2014). South African Informal Traders Forum and Others vs City of Johannesburg and Others; South African National Traders and Retailers Alliance and others vs City of Johannesburg and Others [2014] ZACC8. 
City of Johannesburg (CoJ) (2014). Proclamation of Trading Restricted Areas and Designation of New Trading Areas Council in Inner City Johannesburg. Council resolution passed $22^{\text {nd }}$ of May.

CoJ (2013). Progress of the Inner City Informal Trading Task Team. Report circulated to the main street trader organisations, Office of the Chief Operational Officer, 12 November.

CoJ (2009 [promulgated 2012]). City of Johannesburg Metropolitan Municipality Informal Trading By-Laws. Published in Provincial Gazette extraordinary n66, dated 14 March 2012 under Notice Number 328.

CoJ (2007 [promulgated 2009]). Informal Trading Policy for the City of Johannesburg.

CoJ (2006). Growth and Development Strategy.

Department of Economic Development (DED), (2016a). Presentation to Inner City Informal Trading Sector, Promulgation of Trading Areas. City of Johannesburg, powerpoint presentation for a participatory workshop with informal traders, 26 April, Johannesburg.

DED (2016b). Inner City Informal Trading Plan. City of Johannesburg, powerpoint presentation for a participatory workshop with informal traders, 26 April, Johannesburg.

Greater Johannesburg Metropolitan Council (GJMC) (1998). Management of Informal Trading: Creation of Restricted and/or Prohibited areas. Report presented by the Urban Development Committee: Southern Metropolitan Local Council (SMLC), and voted in SMLC Council, June.

Muhle Unlimited Designs (2008). Master Business Plan: Linear Markets for the Inner City of Johannesburg. Report for the Metropolitan Trading Company (MTC), Johannesburg.

Republic of South Africa (1991 [amended 1993]). Businesses Act. n. 71. In Government Gazette, 311 (13266).

Cape Town, 24 May.

\section{Endnotes}

${ }^{1}$ City official, informal conversation, 25.02.2015.

${ }^{2}$ As a member of the Center for Urbanism and the Built Environment Studies (CUBES) I was approached by street trader organisations to assist them through research in developing counter-proposals for street trading management to the City of Johannesburg. I ended up facilitating workshops with seven inner city street trader organisations, monthly for about two years, fostering joint actions. In parallel and on this basis, I contributed to a Wits University's contracted report to the City of Johannesburg (Zack et al., 2015): this gave me further opportunities to present and debate alternative street trading management models with a variety of City officials. My position is therefore one of sympathy for the street traders, but also one of trying to understand, unpack and respond to the challenges of governing street trading in the city.

${ }^{3}$ Defined here as an area of state intervention (and not as a consistent set of economic activities).

${ }^{4}$ It is in this sense that the term is used to analyse South Africa under late apartheid, where urban movements organised mass protests in the 1980s to "render the city ungovernable", in particular against the Black Local Authorities set up by the apartheid regime to govern the townships in the late 1970s (Bozzoli, 1996).

${ }^{5}$ For a detailed reflection on the methodology that has rendered this paper possible, see Author (in press).

${ }^{6}$ By restrictive approach to street trading, I mean an approach framed by the intention to severely limit the number of traders allowed to trade on the streets, as opposed to an approach aiming at accommodating existing street traders as much as possible. It implies fixing an arbitrary number of legal street trading sites (that is presented as fixed but in reality is being contested and keeps shifting), independently of the number of existing street traders - rather than starting from an assessment of reality (based on a census for instance) and looking into how to accommodate (in different ways, and in negotiation with a variety of stakeholders) existing street traders.

${ }^{7}$ I have presented elsewhere (Author, in press) how MTC has in practice developed (functional but opaque) informal instruments to manage inner city street traders, in the absence of an official recognition of their existence in MTC's mandate.

${ }^{8}$ This 2001 census and the figure of 10000 street traders for the inner city is mentioned in: City of Johannesburg (CoJ) (undated, possibly 2001), The rise and rise of hawking in the inner city. Official website, http://www.joburg.org.za/index.php?option=com_content\&task=view\&id=134\&..\#ixzz329ktlwvW, accessed 15 May 2014. 
${ }^{9}$ These queries were followed up by written submissions to the DED - CUBES and the traders' collective repeatedly requested communication on figures of existing traders, to no avail.

${ }^{10}$ Another reason was to further reduce the number of authorised trading sites (to 1500 authorised trading for about 2700 authorised street traders pre-Operation Clean Sweep : CoJ, 2013) - but this reason was never made explicit. A last (also hidden) motivation could have been to "South Africanise" the traders by the practical exclusion of foreign traders from the list of legal traders, their trading license often being confiscated during the screening process (Author, 2016).

${ }^{11}$ Interview, former CSU official, 2013.

${ }^{12}$ Although this fragmentation is happening through the privatization of security within City Improvement Districts.

${ }^{13}$ Traders often asked City officials in public meeting: "You are providing trading sites for 2700 traders, and you want the rest of us out of the streets. What jobs are you providing for us? We are providing jobs for ourselves, what is your alternative?" (for instance DED public meeting with traders, Johannesburg, 26 April 2016). 